\title{
各種コンクリート壁体の収縮挙動 \\ A STUDY ON SHRINKAGES OF SEVERAL KINDS OF CONCRETE WALLS
}

\author{
今 本 啓一* \\ Keiichi IMAMOTO
}

\begin{abstract}
This paper deals with shrinkages of several kinds of concrete walls. Three types of coarse aggregate were used in this study; normal coarse aggregate, recycled concrete coarse aggregate as grade 1 and grade 3. Elastic modulus, drying shrinkage strains and creep strains of concrete specimens and shrinkage strains of the walls were measured. Based on the mechanical properties of concrete, the shrinkage strains of walls were simulated by a step-by-step method. Following conclusions were obtained.

Shrinkage strains of concrete walls varied with the type of coarse aggregate. A relationship between tensile strain capacities and days at cracking in concrete walls was similar to previous data using cracking frame of JIS "Testing method on cracking of concrete due to restrained drying shrinkage". Good agreements were obtained between the measured strains and computed values in concrete walls.
\end{abstract}

Keywords : concrete wall, shrinkage, creep, elastic modulus, tensile strain capacity, step-by-step method

1. はじめに

コンクリートの乾燥収縮は構造物のひび割れ発生の主要な原因の 一つである。コンクリートの乾燥収縮に起因するひび割れが問題に なる部位として，建築構造物では一般に壁体があげられる。コンク リート壁体の乾燥収縮応力を対象とした解析的研究として, 中西 ${ }^{1)}$, 小柳ら ${ }^{2)}$, 大野ら ${ }^{3)}$ の研究等がある。中西はコンクリート壁体に発生 する主応力分布を把握する目的で F.E.M.による解析を行い, ひび割 れ発生位置との適合性を検証している 。小柳らは壁を拘束する上下 梁部材の経時的なずれおよび梁部材のクリープ・乾燥収縮を考慮し た増分解析法を誘導し, 平屋建て建築物に発生したひび割れの原因 推定を行っている ${ }^{2)}$ 。大野らは室内に存置した複数種類の壁試験体を 対象とし, F.E.M.による増分解析によりそのひずみ挙動を追跡してい る ${ }^{3)}$ 。大野らの研究は, この点において, ひずみ挙動の解析精度を検 証した数少ない事例といえる。但し物性值に既往のモデルコードを 用いている点も含めて, 実大部材を対象としたひずみ挙動の解析に 関する蓄積は必ずしも十分とはいえないと考える。

一方，コンクリートの収縮応力が発生し，それがひび割れ発生に 至るか否かを判定するためには，ひび割れ発生規準による検証が必 要となる。応力レベルでひび割れ発生規準を検討したものとして， 牧角ら ${ }^{4)}$, 大野ら ${ }^{5}$ の研究がある。牧角らは一軸拘束型の供試体によ るひび割れ時の収縮応力強度比（割裂引張強度に対する収縮応力の 比）とひび割れ発生材齢との関係を検討し，引張クリープ限に関す る既往の研究も踏まえて, 収縮応力強度比は 0.7 程度であることを示
している ${ }^{4)}$ 。大野らは JIS 原案の小型供試体を用いた検討を行い，収 縮忘力強度比は, 必ずしも一定の值ではなく，材齢とともに増加す

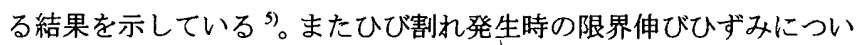
ても検討を行い，ひび割れ発生材齢が長くなるほど限界伸びひずみ も大きくなることを示している。これらはいずれも小型の供試体を 用いた室内実験に基づく結果である。実物大に近い部材を対象とし てひずみ挙動, 収縮応力の点からひび割れ発生に至る挙動を検討す ることができれば，室内実験で蓄積されたこれらの知見との照合も 可能となり，有効なひび割れ制御技術の確立に寄与することができ ると考える。以上をふまえ，本研究は，近年実用化が図られている 再生粗骨材を用いたコンクリートも含めて以下の検討を行うもので ある。

(1)柱梁付壁模擬部材（以下，壁模擬部材）のひび割れ発生時（直前） の限界伸びひずみ，収縮応力強度比について，既往の小型供試体 を対象とした室内実験結果と比較検討する。

(2)模挺壁部材における上下梁部材の分割打設にともなう経時的なず れおよび部材そのもののクリープ・収縮・ヤング係数の変化を考 虑した, step-by-step 解析方法を誘導し, この解析方法の妥当性を 5 種類のコンクリートによる壁模擬部材の収縮挙動を追跡すること により検証する。

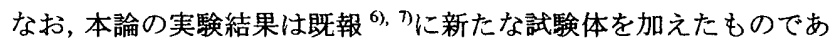
り, 解析結果は既報》で誘導されたものを基に, 新たな試験体にも適 用したものである。 


\section{2. 壁模擬部材の概要}

\section{1 使用材料・計画調合}

本研究では, (1)普通コンクリート(No.1), (2)1 種再生粗骨材コンク リート(No.2), (3)3 種再生粗骨材コンクリート(No.3), (4)3 種再生粗骨 材に減圧・瞬時復圧処理をしたもの(No.4)およびさらに(5) 3 種再生粗 骨材に収縮低減剤を混和して減圧・瞬時復圧処理をしたもの(No.5)の 5 種類のコンクリートを用いた。コンクリートの使用材料を表 1 , 計 画調合を表 2 に示す。減圧・瞬時復圧処理は骨材・コンクリート界 面の強化を目的としたものであるが，その概要については既報 のを参 照されたい。

表 1 使用材料

\begin{tabular}{|c|c|}
\hline セメント:C & 普通ポルトランドセメント（密度 $3.16 \mathrm{~g} / \mathrm{cm}^{3}$ ) \\
\hline \multirow{3}{*}{ 粗骨材:G } & - 普通骨材（砕石）表乾密度 $2.68 \mathrm{~g} / \mathrm{cm}^{3}$ 、吸水率 $0.81 \%$ 、 \\
\hline & - 再生 1 種：表乾密度 $2.57 \mathrm{~g} / \mathrm{cm}^{3}$ 、吸水率 $2.52 \%$ \\
\hline & - 再生 3 種 : 表乾密度 $2.46 \mathrm{~g} / \mathrm{cm}^{3}$ 、吸水率 $5.11 \%$ \\
\hline \multirow{2}{*}{ 紐骨材:S } & $\begin{array}{l}\mathrm{S} 1 \text { 山砂: 表乾密度 } 2.56 \mathrm{~g} / \mathrm{cm}^{3} \text { 、吸水率 } 2.13 \% \\
\mathrm{~S} 2 \text { 砕砂 : 表乾密度 } 2.66 \mathrm{~g} / \mathrm{cm}^{3} \text { 、吸水率 } 1.86 \% \text { (S1:S2=7:3) }\end{array}$ \\
\hline & S3 山砂，表乾密度 $2.55 \mathrm{~g} / \mathrm{cm}^{3}$ 、吸水率 $1.98 \%$ \\
\hline 混和剂 & 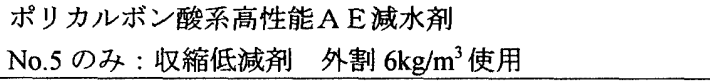 \\
\hline
\end{tabular}

\section{2 壁模擬部材の形状}

壁のひずみ挙動を検討するための壁模擬部材の形状を図 1 に示す。 壁模擬部材の下梁には全て No.2 の調合のコンクリートを用い，直接 コンクリート土間の上に作製した。上部コンクリートの打込み時期 および型伜の取り外し時期は，普通骨材，再生 1 種粗骨材を用いた コンクリート（No.1，2）で材龄 30 日および打ち込み後 8 日，再生 3 種粗骨材を用いたコンクリートで材齢 31 日および打ち込み後 7 日と した。壁模擬部材の上梁上面は型枠取り外しまでビニルシートで養 生した。なお模擬部材の打設に併せて, 同一鉄筋比の壁および上梁 （柱）のダミー部材（図 1 下参照）を作製し，埋込み型ひずみ計に より，部材中心部のひずみを測定した。ダミ一部材の型枠脱型時期 は模擬部材の型枠取り外し時期と同一とした。

\section{3 コア抜き用部材（無筋）}

構造体（コア）強度・ヤング係数を調查するため, 綐 $400 \times$ 横 600 ×高さ $420 \mathrm{~mm}$ の無筋のコア抜き用部材を作製し，気中養生材龄 7,28,56,91 日の時点でそれぞれコンクリートコアを 2〜4 本抜き取り， 圧縮強度およびヤング倸数を求めた。

\section{3 実験結果}

\section{1 フレッシュコンクリート試験結果}

打設前の，各コンクリートのスランプ，空気量および高周波加熱乾 燥法による単位水量試験結果を表 3 に示す。単位水量は概ね計画値 を満足する結果となっている。

表 2 計画調合

\begin{tabular}{|c|c|c|c|c|c|c|c|c|c|c|c|}
\hline \multirow{2}{*}{ No. } & \multirow{2}{*}{ 粗骨材の種類 } & \multirow{2}{*}{$\begin{array}{l}\text { W/C } \\
(\%)\end{array}$} & \multirow{2}{*}{$\begin{array}{l}\text { 粗骨材かさ } \\
\text { 容積 }\left(\mathrm{m}^{3} / \mathrm{m}^{3}\right)\end{array}$} & \multirow{2}{*}{$\begin{array}{l}\text { s/a } \\
(\%)\end{array}$} & \multicolumn{5}{|c|}{ 単位量(kg/m³ $)$} & \multirow{2}{*}{$\begin{array}{l}\text { 混和剤 } \\
(\mathrm{C} \times \%)\end{array}$} & \multirow{2}{*}{ 備考 } \\
\hline & & & & & W & $\mathrm{C}$ & $G$ & $\mathrm{~S} 1+\mathrm{S} 2$ & S3 & & \\
\hline 1 & 普通骨材 & \multirow{5}{*}{50} & \multirow{2}{*}{0.600} & 47.3 & \multirow{5}{*}{180} & \multirow{5}{*}{360} & 933 & 811 & - & 0.79 & - \\
\hline 2 & 再生 1 種 & & & 43.6 & & & 959 & - & 740 & 1.20 & - \\
\hline 3 & \multirow{3}{*}{ 再生 3 種 } & & \multirow{3}{*}{0.590} & \multirow{3}{*}{45.8} & & & \multirow{3}{*}{899} & \multirow{3}{*}{-} & \multirow{3}{*}{773} & \multirow{2}{*}{1.70} & - \\
\hline 4 & & & & & & & & & & & 減圧・瞬時復压処理 \\
\hline 5 & & & & & & & & & & 3.70 & No.4+収縮低減昘 \\
\hline
\end{tabular}
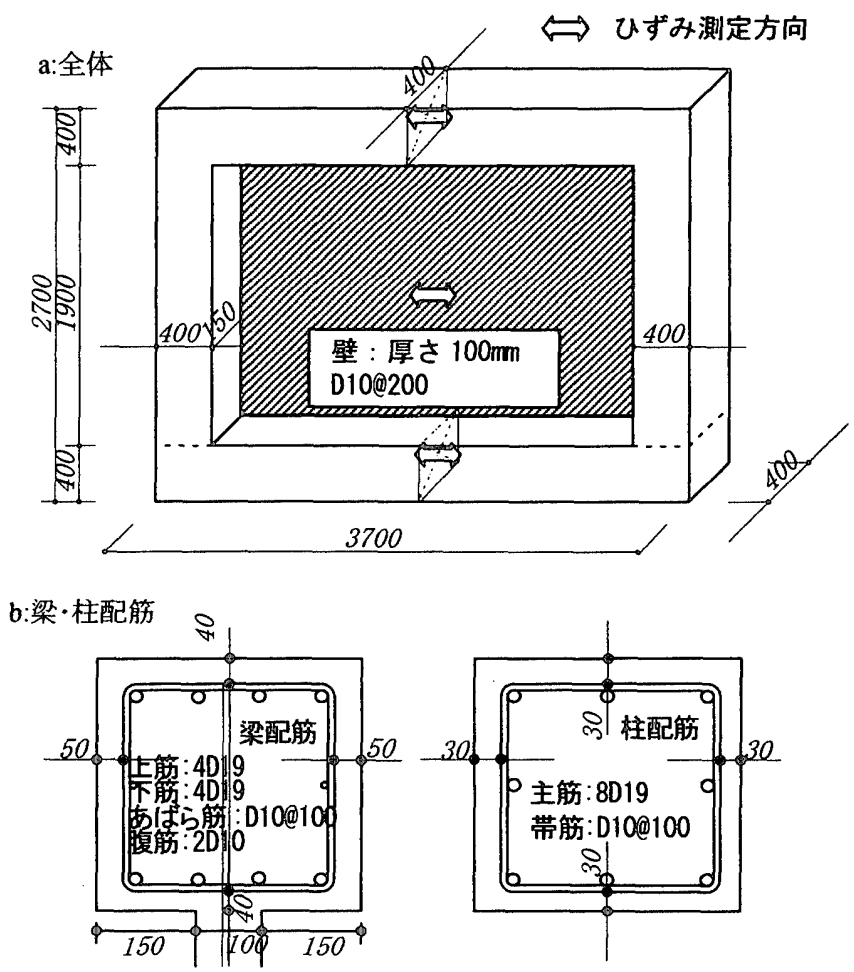

c:ダミー部材

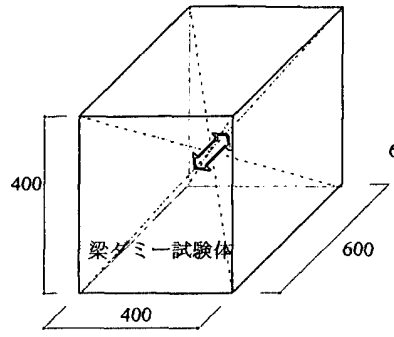

$\Leftrightarrow$ ひずみ測定方向

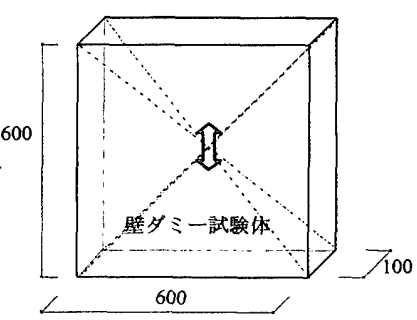

図 1 壁模擬部材等(上: 全体, 中 : 梁·柱配筋，下：ダミ一部材)

\begin{tabular}{|c|c|c|c|c|}
\hline No. & $\begin{array}{c}\text { 粗骨材の } \\
\text { 種類 }\end{array}$ & $\begin{array}{c}\begin{array}{c}\text { スランプ } \\
\mathrm{cm}\end{array} \\
\end{array}$ & $\begin{array}{c}\text { 空気量 } \\
\%\end{array}$ & $\begin{array}{c}\text { 単位水量 } \\
\mathrm{kg} / \mathrm{m}^{3}\end{array}$ \\
\hline 1 & 普通骨材 & 18.0 & 4.8 & 178.9 \\
\hline 2 & 再生 1 種 & 20.2 & 5.0 & 184.9 \\
\hline 3 & \multirow{3}{*}{ 再生 3 種 } & 20.5 & 5.1 & 180.1 \\
\hline 4 & & 20.5 & 3.5 & 180.5 \\
\hline 5 & & 22.0 & 6.7 & 178.9 \\
\hline
\end{tabular}

\section{2 圧縮強度, ヤング係数の变化}

コア抜き用部材から得られた圧縮强度の変化を図 2 に示す。コンク リートの圧縮強度は堿圧・瞬時復圧処理をしたもの(No.4)が最も大き い。ヤング係数の変化および CEB-FIP Model Code1990 果の一例（No.1）を図 3 に示す。近似は図中に示す式・係数により行 い，いずれの試験体についても近似精度が良いことを確認している。 


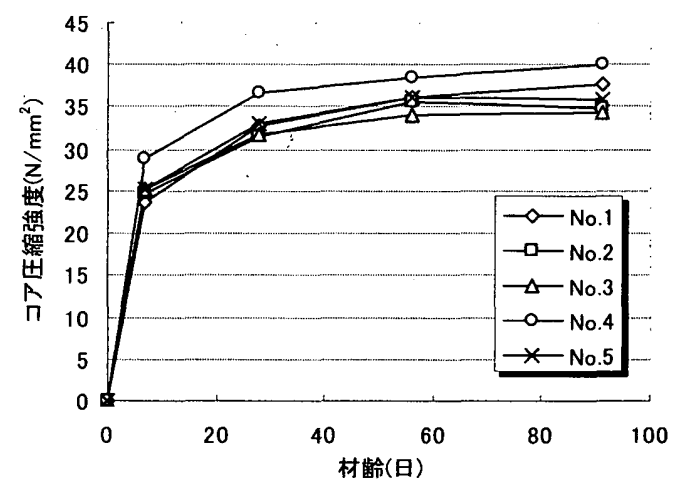

図 2 圧縮強度の変化

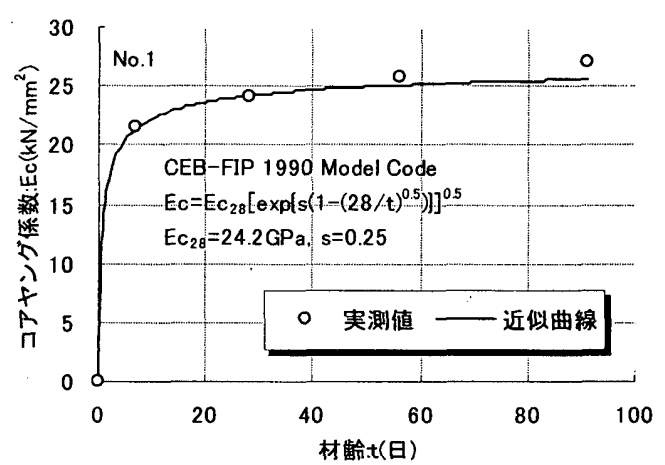

図 3 ヤング係数の変化(No.1)

\section{3 各種コンクリートの圧縮クリープ・収縮性状}

各種コンクリートの圧縮クリープ・収縮ひずみは，後述する実大 模擬壁と同一の存置場所とし，雨がかりのない屋内において計測を 行った。ひずみの測定は $\phi 100 \times 200 \mathrm{~mm}$ 供試体（無筋）を用い，埋込 みゲージにより行った。乾橾開始までは封絾養生とし, 乾燥および クリープの載荷は材㱓 7 日で行った。載荷応力は載荷時強度の約 $1 / 3$

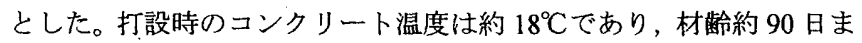

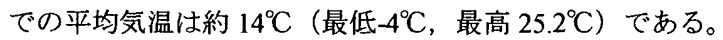

収縮ひずみの変化を図 4 に示す。図に示されるように, 収縮ひずみ は材齢約 130 日の時点で約 $200 \times 10^{-6}$ の差が生じており, その大きさ は再生 3 種粗骨材（No.3）>再生 3 種十減圧・瞬時復圧（No.4）>普 通骨材 (No.1) > 再生 1 種（No.2）>再生 3 種十収縮低減剂十減圧 瞬時復圧 (No.5) となっている。再生 3 種粗骨材では普通骨材よりも 乾燥収縮が大きいのに対して再生 1 種では逆に小さくなっている。こ の理由として, 再生 3 種では表面の付着モルタルの影響が卓越してい るのに対し, 付着モルタル量の小さい再生 1 種では原骨材の違いが顕 著に出たことが考えられる。収縮低减剤については, 再生粗骨材を対 象とした既往の研究においてその効果が指摘されており ${ }^{9}$, 本研究で 用いた骨材においても同様の収縮低減効果が得られている。减圧・瞬 時復圧処理の効果は特に見られない6)。

圧縮クリープひずみの変化を図 5 に示寸。図に示されるようにコン クリートの単位応力度当たりのクリープひずみは材龄約 130 日の時 点で約 $40 \times 10^{-6}$ の差となり，その大きさは再生 3 種粗骨材. (No.3) > 普通骨材 (No.1) > 再生 3 種十堿圧・瞬時復圧 (No.4) ○再生 1 種 (No.2) $>$ 再生 3 種十収縮低減剤十减圧・瞬時復圧（No.5）である。

\section{4 壁模擬部材のひび割れ性状}

壁模擬部材のひび割れ発生材齢は，No.3（14 日）<No.4（20日）

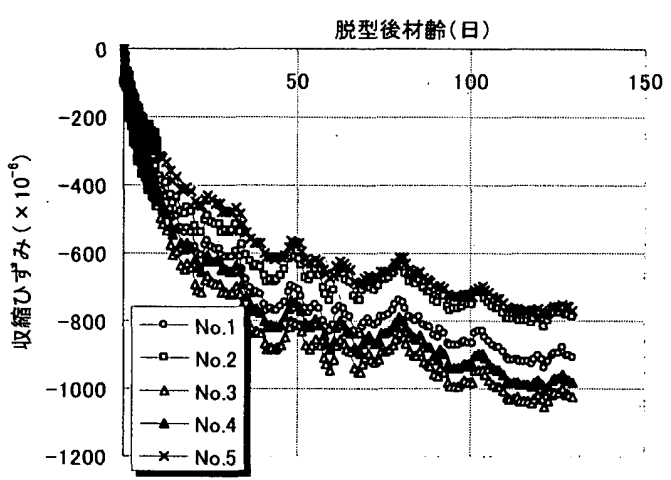

図 4 収縮ひずみの変化 $(\phi 10 \times 20 \mathrm{~cm})$

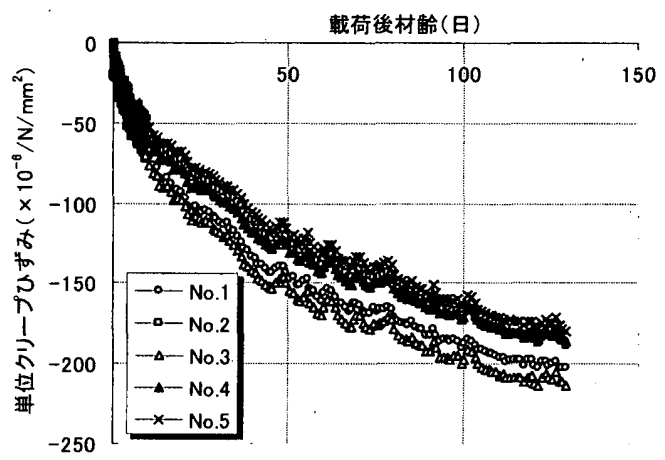

图 5 クリープひずみの変化 $(\phi 10 \times 20 \mathrm{~cm})$

$<$ No.1（36 日） <No.5（51 日）<No.2（108 日）の順（後述図 11 15 参照）である。試験体には壁四隅の微細なひび割れと中心部付近 のほぼ垂直方向に貫通した比較的大きなひび割れが発生した。クラ ッスケールで計測した, 材齢約 1 年時点における中心部付近 のひび割れ幅の分布は図 6 に 示す通りである。平均ひび割れ 幅は, No.3 (0.20mm) >No.4 $(0.19 \mathrm{~mm})>$ No.1 $(0.17 \mathrm{~mm})$ $>$ No.5 (0.14mm) > No.2 (0.10mm) となっており，ひ び割れ発生材齢の順と概ね一 致している。つまり骨材の種類 にかかわらず,早期にひび割れ が発生したものほどひび割れ 幅が大きくなる傾向が認めら れ、ひび割れ幅の制御において は,ひび割れ発生材齢に関する 検討が重要と考える。

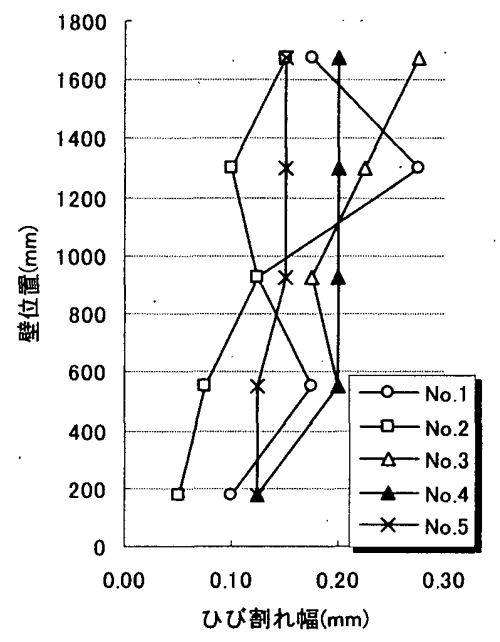

図 6 ひび割れ幅の分布（材龄約 1 年）

\section{4 考察}

\section{1 ひび割れ発生時（直前）の限界伸びひずみ}

ひび割れ発生材龄とひび割れ発生直前の限界伸びひずみの関係につい て JIS 原案の小型供試体を用いた大野らの室内実験結果 "を基に検討を 行う。限界伸びひずみは, 後述図 11〜15に示される壁模擬部材の壁部中 央ひずみより壁ダミ一部材のひずみを差し引くことにより求めた。大野 らの論文に示されるひび割れ発生材龄と限界伸びひずみの関係に対して， 本研究の結果をプロットしたものを図 7 に示す。図に示されるように, 
本研究における壁模擬部材の限界伸びひずみはひび割れ発生材龄が長く なるとともに大きくなる傾向にあり，その大きさも室内実験結果と概ね 一致すると判断される。このことから本研究の範囲内では, 骨材の種頑 にかかわらず，壁模擬部材の限界伸びひずみについて既往の室内実験の 知見を概ね適用することが可能であると思われる。

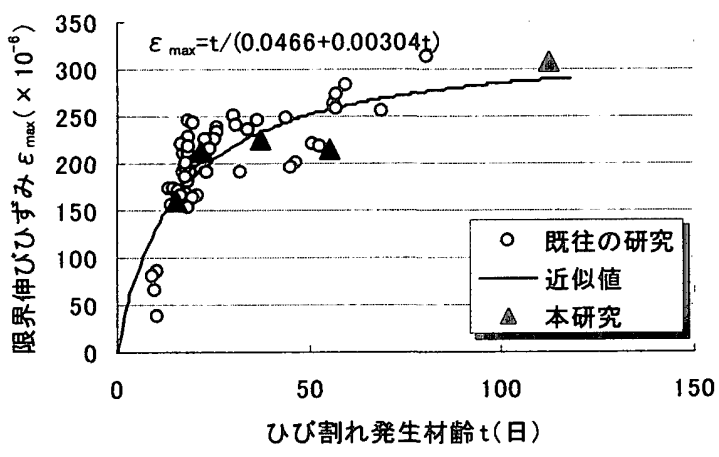

图 7 ひび割れ発生材龄と限界伸びひずみの関係(文献5)を基に作成)

\section{2 ひひ割れ発生時（直前）の収縮応力強度比}

ひび割れ発生材齢と收縮応力強度比（割裂引張強度に対する收縮応 力の比）の関係について，4.1 と同様に大野らの研究を基に検討を行う。 壁模擬部材は拘束・非拘束部材間のクリープ・収縮・ヤング釈数の複合 要因の影響を受けるため, JS 原案の試験体のように拘束銅材のひずみか ら直接的に収縮応力を求めることはできない。そこでここでは，壁模擬 部材の壁中央ひずみから壁ダミー部材のひずみを差し引いたものを拘束 ひずみとして, step-by-step 法に基づく下式により収縮応力の推定を行う。

$\sigma\left(t_{i+1 / 2}\right)=\frac{1}{J\left(t_{i+1 / 2}, t_{i}\right)}\left\{\varepsilon\left(t_{i+1 / 2}\right)-\varepsilon_{e}\left(t_{i-1 / 2}\right)-\varepsilon_{f}\left(t_{i+1 / 2}\right)\right\}_{(1)}$

ここに,

$J\left(t_{i+1 / 2}, t_{i}\right)=\frac{1}{E\left(t_{i}\right)}+\frac{\phi\left(t_{i+1 / 2}, t_{i}\right)}{E_{28}}$

$\sigma\left(t_{i+1 / 2}\right):$ ステップ $t_{i+1 / 2}$ でのコンクリート応力 $\left(N / \mathrm{mm}^{2}\right)$

$\varepsilon\left(t_{i+1 / 2}\right):$ ステップ $t_{i+1 / 2}$ での実ひずみ $三$ 壁模擬部材ひずみ

$\varepsilon_{f}\left(t_{i+1 / 2}\right):$ ステップ $t_{i+1 / 2}$ での自由ひずみ $\fallingdotseq$ 壁ダミーひずみ

$\phi\left(t_{i+1 / 2}, t_{j}\right):$ ステップ $t_{j}$ で載荷されたステップ $t_{i+1 / 2}$ でのクリープ係数 $E\left(t_{i}\right):$ ステップ $t_{i}$ でのヤング係数 $\left(\mathrm{N} / \mathrm{mm}^{2}\right)$

$E_{28}:$ 標準養生材齢 28 日ヤング係数 $\left(\mathrm{N} / \mathrm{mm}^{2}\right)$

$\varepsilon_{e}\left(t_{i-1 / 2}\right)=\sum_{j=1}^{i} \Delta \sigma\left(t_{j}\right) J\left(t_{i+1 / 2}, t_{j}\right)-J\left(t_{i+1 / 2}, t_{i}\right) \sigma\left(t_{i-1 / 2}\right)$

図 8 にクリープ係数の一例（No.1）を示す。本論におけるクリープ 係数は，材龄 28 日のヤング係数を用いた場合の弾性ひずみに対する クリープひずみの比である。図 5 で得られた実測値を基に, 载荷時 材跉および部材体積表面積比(v/s)を考虑することのできる提案式 ${ }^{10)}$ を用い, テストピースの v/s を用いて近似した。解析ではこの値を基 に, 壁部材および梁部材の $\mathrm{v} / \mathrm{s}$ に応じたクリープ係数を算定して用い た。また後述の解析に供するため, 近似は, ひび割れ発生材齢まで を対象とした。なお，提案式提案式による值と実測值の乘離を埋め るため, 図に示す倍率を乗じている。この倍率は特にひび割れ発生 までの材齢が短い試験体では大きい（最大：No.3の 2.5 倍）が，これ
は, 提案式構築の元になったデータが長期材齢（平均材龄約 400 日） を対象としており，短期の実験值に適合しない点があるためと思わ れる。ヤング倸数は CEB-FIP Model Code1990による近似式を用いた。

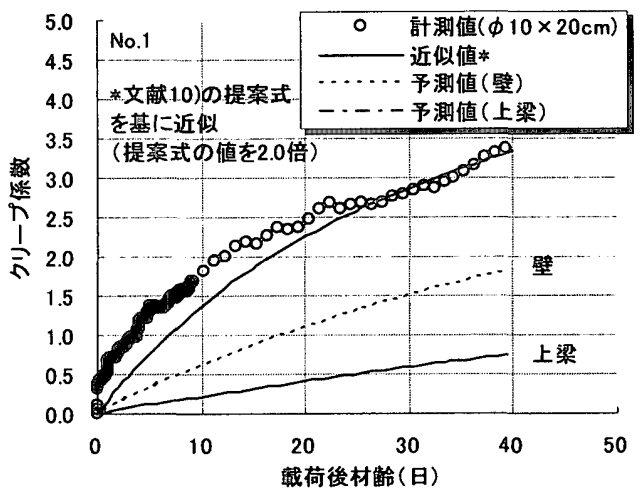

图 8 クリープ係数の変化と壁・上梁の予測曲線 (No.1)

ひび割れ発生時の割裂引張強度は, 材齢 28 日標準水中養生の割裂強度 (No.1 : 2.72, No.2 : 2.76, No.3: 2.88, No.4:2.56, No.5 $: 2.26\left(\mathrm{~N} / \mathrm{mm}^{2}\right)$ ) を基に, CEB-FIP Model Code 1990 に準拠した次式により推定した。

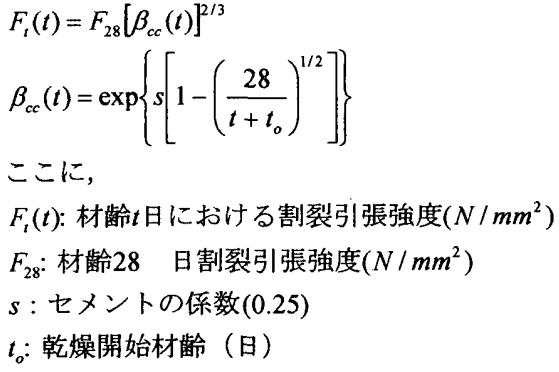

JS 原案の小型供試体を用いた大野らのデータ 5)を引用して作成した， ひび割れ発生材齢と収縮応力強度比の関係に本研究の結果をプロットし たものを図 9 に示す。大野らの検討はひび割れ発生時の割裂引張強度を 逐次詳細に試験した結果に基づくものであるのに対し，本検討はひび割 れ発生時の収縮応力, 割裂引張強度のいずれも推定值である。したがっ て本研究にお打る収縮応力強度比と既往の研究は一概に比較はできない が, ひひ割れ発生材齢が長くなるほど収縮応力強度比が大きくなる点で 概ね傾向が一致している。

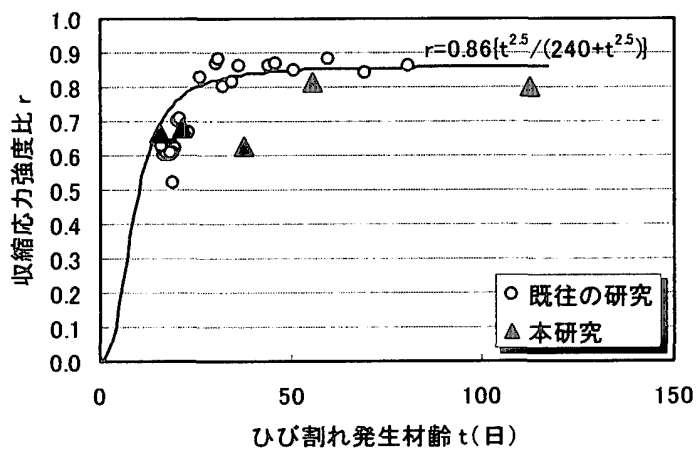

図 9 ひび割れ発生材齢と収縮応力強度比の関係(文献 5)を基汇作成)

ひび割れ発生時の限界ひずみ, 収縮応力強度比の時間依存性は, 部材断 面内の湿度勾配に伴う内部拘束応力の影響によると考えられ, より原理 的にひび割れ挙動を捉えるためには，今後この評洒が必要と考える。 


\section{3 壁模擬部材の収縮変形挙動解析 \\ (1) 解析式の誘導}

本研究では，壁模擬部材を一次元モデルと捉え，ひび割れ発生材 齢までのひずみ挙動を step-by-step 法で追跡することを試みる。解析の 基本式は式(1)に示すとおりである。壁体・上下梁部材においてカの 釣り合いが成立する場合,

$E_{e}\left(t_{i+1 / 2}, t_{j}\right) A\left\{\varepsilon\left(t_{i+1 / 2}\right)-\varepsilon_{e}\left(t_{i-1 / 2}\right)-\varepsilon_{f}\left(t_{i+1 / 2}\right)\right\}:$ 壁中立軠位避の引張力 $+E_{e}^{\prime}\left(t_{i+1 / 2}, t_{j}\right) A^{\prime}\left\{\varepsilon^{\prime}\left(t_{i+1 / 2}\right)-\varepsilon_{e}^{\prime}\left(t_{i-1 / 2}\right)-\varepsilon_{f}^{\prime}\left(t_{i+1 / 2}\right)\right\}:$ 上梁の压縮力 $+E_{e}^{\prime \prime}\left(t_{i+1 / 2}, t_{j}\right) A^{\prime \prime}\left\{\varepsilon^{\prime \prime}\left(t_{i+1 / 2}\right)-\varepsilon_{e}^{\prime \prime}\left(t_{i-1 / 2}\right)-\varepsilon_{f}^{\prime \prime}\left(t_{i+1 / 2}\right)\right\}:$ 下梁の圧籍力 $=0$

となりここに,

$E_{e}\left(t_{i+1 / 2}, t_{i}\right)=\frac{1}{J\left(t_{i+1 / 2}, t_{i}\right)}$

$\mathrm{A}, \mathrm{A}^{\prime}, \mathrm{A}^{\prime \prime}$ : 壁体, 上梁, 下梁の断面積

'：上梁のサフィックス," : 下梁のサフィックス

これらに加え, 上梁, 下梁が分担する圧縮力が等しいこと(式(4))， およびひずみの平面保持（式(5)）を仮定することにより，上梁と下 梁を分割打設した場合において壁体に生じる态力，ひずみ举動を Step-by-step で追跡することが数式上可能となる。

$E_{e}^{\prime}\left(t_{i+1 / 2}, t_{i}\right) A^{\prime}\left\{\varepsilon^{\prime}\left(t_{i+1 / 2}\right)-\varepsilon_{e}^{\prime}\left(t_{i-1 / 2}\right)-\varepsilon_{f}^{\prime}\left(t_{i+1 / 2}\right)\right\}$

$=E_{e}^{\prime \prime}\left(t_{i+1 / 2}, t_{i}\right) A^{\prime \prime}\left\{\varepsilon^{\prime \prime}\left(t_{i+1 / 2}\right)-\varepsilon_{e}^{\prime \prime}\left(t_{i-1 / 2}\right)-\varepsilon_{f}^{\prime \prime}\left(t_{i+1 / 2}\right)\right\}$

$\varepsilon\left(t_{i+1 / 2}\right)=\frac{\left\{\varepsilon^{\prime}\left(t_{i+1 / 2}\right)+\varepsilon^{\prime \prime}\left(t_{i+1 / 2}\right)\right\}}{2}$

\section{（2）解析精度の検証}

ヤング俰数は CEB-FIP Model Code1990による計算值を用いた。ク リープ係数は図 8 に示される壁部材および梁部材に対応するクリー プ俰数を算定して用いた。図 10 に上梁ダミー部材の収縮びずみの変 化（No.1）を示す。いずれの試験体についても, 解析では図に示す双 曲線式による近似式を用いた。先行打設した下梁ひずみは，土間の拘 束により，壁・上梁打設時には既に，図に示されるように，見措け上収 縮が収束した傾向が認められたため, 解析では収縮ひずみを 0 とした。

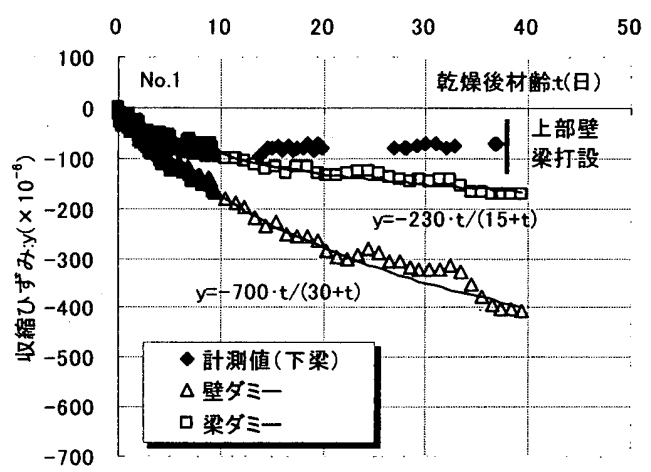

図 10 ダミー部材の収縮ひずみの変化（No.1）
ひび割れ発生材齡までの各壁模擬部材のひずみの変化と解析結果を図 11〜15に示す。いずれの試験体においても，壁ダミー部材ひずみ>模 擬壁ひずみ，模擬上梁ひずみ>梁ダミーひずみとなっている。これ は, 壁は上・下梁の拘束を受けるため, 上梁では壁の収縮によって 圧縮力を受けるためと考えられる。上梁と下梁について，下梁は部 材の剛性が大きく乾燥収縮も小さいため, ひずみは小さい。図に示さ れるように，解析結果（各図中実線）は，試験体各部のひずみ

口）と概ね一致しており，本検討の範囲内では，前述(3)〜(5)に示される 前提条件に基づく Step-by-step 法により, 壁模擬部材の収縮変形挙動を概 ね精度良く解析できることが示されている。

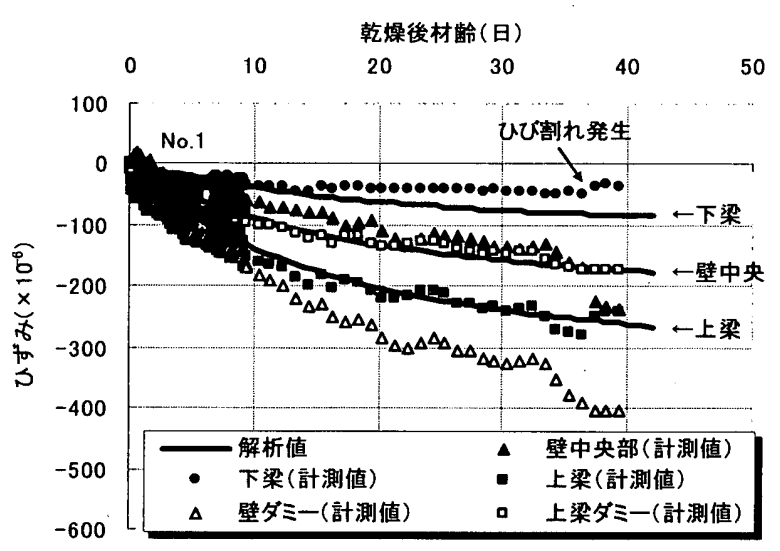

図 11 壁模擬部材のひずみの変化と解析結果（No.1）

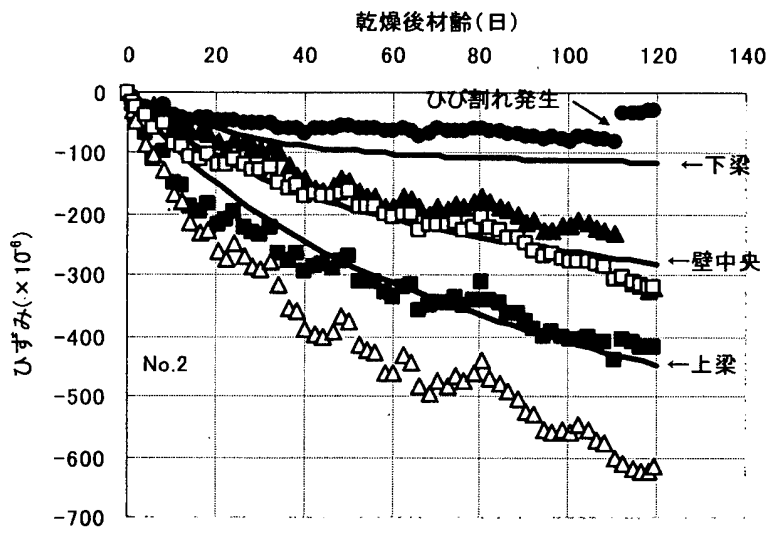

図 12 壁模擬部材のひずみの変化と解析結果（No.2）

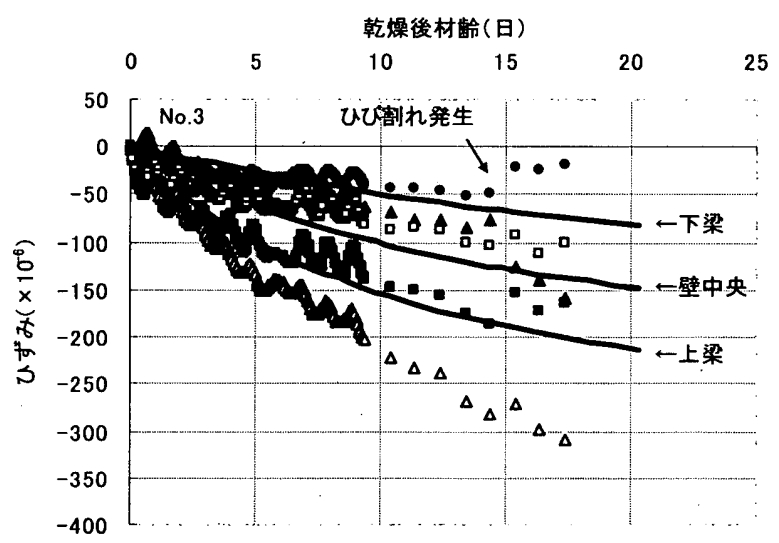

図 13 壁模擬部材のひずみの変化と解析結果（No.3） 


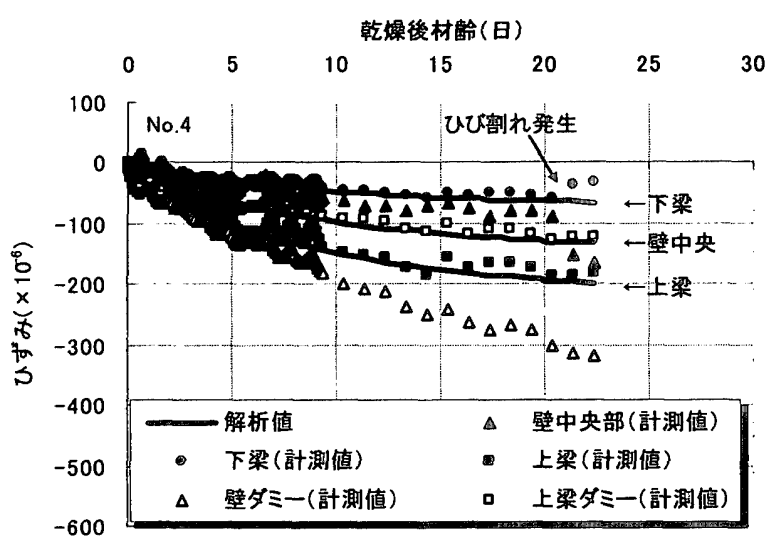

図 14 壁模擬部材のひずみの変化と解析結果（No.4）

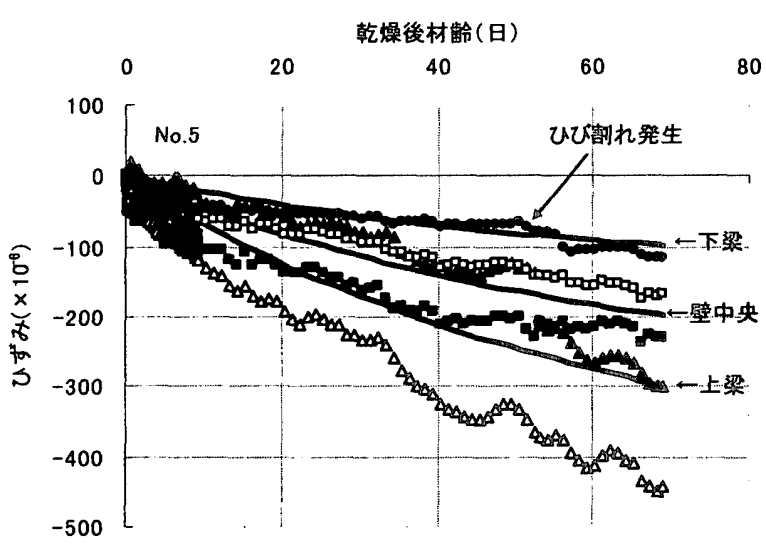

図 15 壁模擬部材のひずみの変化と解析結果（No.5）

4.2 に示される模擬壁の実測ひずみより算定した応力と(3)〜(5)式に基 つく Step-by-step 法による解析応力を比較したものを図 16 に示す。両者 の間には概ね良い一致が認められ，このことからも(3)〜(5)式に基づく Step-by-step 法は壁体の収縮挙動の解析法として有効であると考えられ る。今後さらに, ひひ割れ発生以降のひび割れ幅の進展挙動の解析方法 を検討することにより，合理的なひび割れ制御手法を構筑することが可 能であると考えられる。

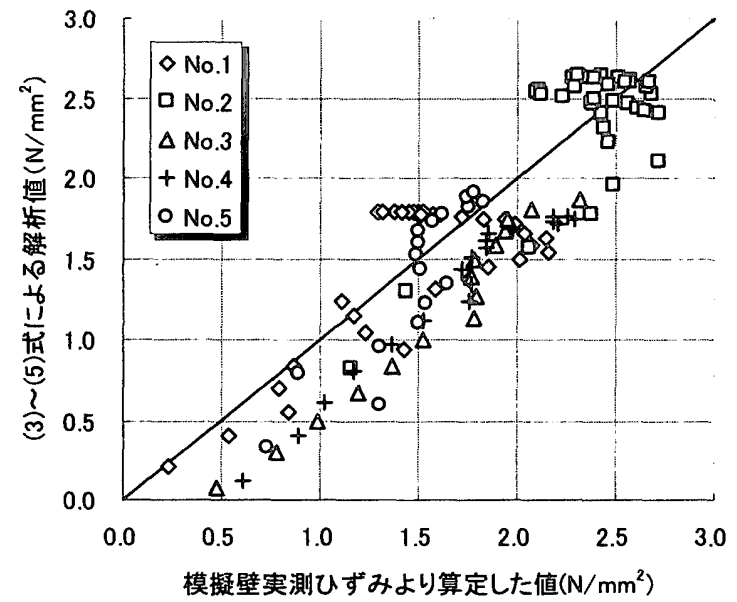

図 16 実測ひずみより算定した応力と (3) (5)式に基づく解析応力の比較
5. まと的

普通骨材，再生 1 種および 3 種粗骨材を用いた 5 種類のコンクリート により実大壁模擬部材を作製した。壁体部のひび割れ幅とひび割れ発生 材龄に概ねの相関があることを踏まえ，ひび割れ発生材跉に及ぼすひび 割れ発生時 (直前) の限界伸びひずみ，収縮応力強度比の影響をついて， JIS 原案の小型供試体を用いた既往の室内実験と比較検討した。さらに, 壁模擬部材の収縮举動の Step-by-step 法による解析を試みた。本研究の範 囲内で得られた知見を以下に示す。

1)壁模雉部材の限界伸びひずみ，収縮応力強度比（割裂引張強度に 対する収縮応力の比）は，骨材の種類にかかわらず，ひび割れ発 生材齢が長くなるほど大きくなる傾向にあり，JIS 原案の小型供試 体を用いた既往の室内実験と概ね一致する結果となった。

2）壁模擬部材の収縮挙動は，壁体および上下梁部材における力の釣 り合い, 上下梁部材の力の分担の同一性およて壁模擬部材における ひずみの平面保持を仮定した Step-by-step 法により概ね精度良く解 析できることを示した。

ひび割れ発生時の限界ひずみ，収縮応力強度比の時間依存性は，部材 断面内の湿度勾配に伴う内部拘束応力の影響によるものと考えられる。 より原理的にひび割れ挙動を捉えるためには，その影響を評価すること が必要であり，以上を踏まえた上で，ひび割れ幅の制御手法を構筑する ことが今後の課題と考える。

謝辞

本研究における実験は高性能再生コンクリート研究会（会長 森田 司郎 (財)日本建築総合試験所 理事長)において実施されたもので あり，実験データの使用にあたり関係諸氏の御快諾を賜ったことに 深謝いたします。

\section{参考文献}

1）中西正俊：コンクリートの壁面ひびわれ誘発目地位置に関寸る F.E.M.による検討，清水建設研究所報，第 24 号，pp.1-9， 1975.

2）小柳光生他：外壁に作用する乾燥収縮応力に関する一考察，日 本建築学会大会学術講演梗概集, 材料施工, pp.693-694, S.61.8

3）大野義照，鈴木計夫他：コンクリートの一軸拘束ひび割れ試験と壁 試験体の収縮拘束ひび割れ性状, コンクリート工学年次論文報告集, 10-2, pp.261-266, 1998

4) 牧角龍憲，徳光善治: コンクリートの乾燥收縮ひび割れ発生条件に 関する研究, 第 5 回コンクリート工学年次論文報告集, pp.185-184, 1993

5) 大野俊夫, 魚本健人: コンクリートの収縮ひび割れ発生予測に関す る基磷的研究，土木学会論文集，No.662/V-49，29-44，2000.11

6) 今本啓一他：減圧・瞬時復圧処理した再生粗骨材コンクリート の実大模擬部材に㧍ける性状，日本建築学会構造系論文集， No.555, pp.31-36, 2002.5

7) 今本啓一: 梁部材を分割打設したコンクリート壁体の収縮変形 挙動解析ー1 種再生粗骨材コンクリートを対象とした検証一, 日本建築学会学術講演梗概集, 材料施工, 563-564, 2002.8

8) CEB-FIP Model Code 1990, Thomas Telford.

9) 杉山一弥他: 解体コンクリートのコンクリート用骨材への適用性に 関する研究，コンクリート工学論文集，第 7 巻第 1 号, pp.91-101, 1996.1

10） 今本啓一, 山本俊彦: 鉄筋コンクリート部材のクリープ乾燥収 縮特性（その 1: コンクリートのクリープ・乾燥収縮予測式）, 日本建築学会東海支部研究報告, 第 39 号, pp.105-108，2001. 